\title{
Application of Mobile Information System Based on Internet in College Physical Education Classroom Teaching
}

\author{
Jiayi Li 1 \\ College of Physical Education, Henan Institute of Science and Technology, Xinxiang 453000, Henan, China \\ Correspondence should be addressed to Jiayi Li; ljiayi@hist.edu.cn
}

Received 26 August 2021; Accepted 5 November 2021; Published 10 December 2021

Academic Editor: Sang-Bing Tsai

Copyright ( $\odot 2021$ Jiayi Li. This is an open access article distributed under the Creative Commons Attribution License, which permits unrestricted use, distribution, and reproduction in any medium, provided the original work is properly cited.

With the continuous acceleration of China's socialist process, the development of society has made a great leap forward. Mobile Internet is an emerging product of the integration of traditional Internet and mobile communication industries. At present, the industry has not yet reached a unified consensus on the concept of mobile Internet. This research mainly discusses the application of Internet-based mobile information system in college physical education classroom teaching. In order to adapt to the pace of social development and cultivate more intelligent, healthy, and noble students, the education cause also carries out continuous reform and innovation. New educational ideas and new educational methods have been attracting people's attention. More and more people are pursuing higher education level. School education should not only pay attention to the progress of students' academic performance and the sound personality quality, but also pay attention to the implementation of physical education and help students carry out appropriate physical exercise, so as to exercise students' physique and make them realize the importance of physical exercise. As an important link in school physical education teaching, classroom teaching design has a very important influence on teaching quality and classroom teaching effect. For the Internet mobile information system, it can not only improve the ability of physical education teachers to control the teaching process, but also make the teaching objectives and content, teaching strategies and methods, and teaching evaluation formulated by physical education teachers more systematic, thus improving the teaching quality and professional development of physical education teachers. Abundant online teaching resources provide teachers with a powerful information resource database for lesson preparation and teaching. Learners can access teaching resources at any time through the Internet mobile information system. The Internet mobile information system provides a variety of file sharing methods for teachers and students to share physical education resources. Teachers and students forward and share teaching-related resources anytime and anywhere through the network platform, which not only helps to strengthen the students' ability to collect and process information, but also strengthens the communication and cooperation between students through the sharing of learning resources. This study aims to study the problems of university physical education classroom teaching from the perspective of the Internet mobile information system, find the problems existing in university physical education classroom teaching, reasonably solve the educational problems of university physical education classroom teaching, help the development of college sports, and help college students to carry out physical exercise and maintain a strong constitution. The methods adopted in this paper are as follows: firstly, inductive method is used to analyze the survey data; secondly, the case analysis method is used to study the characteristics of curriculum in colleges and universities; finally, after finding the existing problems, comparative research method is used to compare the influence of students, teachers, and leaders in charge on the existing education problems. The conclusion is the lack of theoretical guidance and concept carding in college physical education makes students not form a good lifelong sports consciousness; the positive influence of physical exercise on a person greatly promotes the development of personal lifelong sports; there are unreasonable phenomena in the arrangement of physical education teaching in colleges and universities. The training mode of colleges and universities is mainly based on social practice, and extracurricular activities are mainly for it. In addition, there is a small amount of in-class teaching. 


\section{Introduction}

College physical education is an indispensable aspect of education. Good physical education is helpful to "train human resources, train talents, and improve people's intelligence." Every citizen, especially young people, should "develop wisdom, build up health, inspire spirit, and cultivate sentiment" and become talents to meet the needs of the rejuvenation of the motherland and economic development. "Red head document" [1] clearly points out: "we should build a new youth era with noble moral character, modern science and technology and scientific knowledge, healthy physique and innovative thinking." The task and goal of physical education in colleges and universities is to cultivate and improve the physical quality of students [2], to train a generation of healthy, all-round development, to meet the needs of the national reform process of new talents. Although physical education is a problem that our country attaches great importance to and cares about, there are still many problems in college physical education. The Sports Bureau of the Ministry of education evaluated the situation of school physical education: "people's understanding of the status and role of sports is still subject to many restrictions." The Ministry of Education has some targeted policies to improve the quality of school physical education: "research and reform the content of physical education curriculum, cultivate teachers' teaching methods to meet the students' psychological and school conditions of all grades, and at the same time ensure the physical education teachers, teaching quality [3], teaching methods [4], equipment, curriculum, curriculum, teaching equipment and other conditions in the school synchronization." With the rapid development of physical education curriculum reform, the research of physical education classroom teaching design also showed a blossoming trend. As the fundamental direction and foothold of physical education curriculum reform, the physical education classroom teaching design has a great impact on the process of curriculum reform. Therefore, under the wave of physical education curriculum reform, how to write physical education classroom teaching design, better solve the teaching problems of teachers encountered in teaching practice, and implement the new physical education curriculum standard "health first, student-centered" is the basic concept of all-round development, which need us to continue the exploration and research of physical education classroom teaching design that never stop.

The 21st century is a critical period for China's rapid social and economic development and an important period for realizing the Chinese dream and realizing the great rejuvenation of the Chinese nation. To establish and improve the training system of talent market and to provide talents for social and economic construction is an important link to ensure the stable construction of the country. With the national fitness slogan [5], sport as an important measure to enhance the national physique [6] is related to the great rejuvenation of the Chinese nation and plays an increasingly important role in modern society. The role of physical education [7] is to establish a strong physique, establish personality, not afraid of difficulties, and dare to fight, and physical education teachers play an important role in the process of teaching and training. The cultivation of college students majoring in physical education is not only to cultivate students' certain skills or single professional theoretical knowledge, but also to cultivate students' thinking mode, thinking ability, thinking direction, and practical operation ability. With the development of reform and opening up, Chinese sports have been further improved and enriched with the pace of social and economic development. With the rapid development of science and technology, human society has entered the information age, and the Internet has become an indispensable and important part of people's daily life, playing an increasingly important role. The Internet has become popular, mobile terminals have made unprecedented progress, and people's production and life have undergone great changes. Under the background of the Internet age, it is imperative to reform traditional college physical education. The application of mobile Internet in college physical education can effectively strengthen the communication and interaction between teachers and students, innovate physical education teaching methods, and improve teaching efficiency and improve the quality of teaching. The role of the mobile information system of the Internet in promoting physical education in colleges and universities has further deepened the concepts of lifelong sports and lifelong sports education in colleges and universities.

However, in the face of multiple and complex ability training, it is still unable to solve the contradiction between limited classroom teaching time and long-term ability training and multipractice. The physical education professional practice activities outside the physical education curriculum are not limited by time, place, content, and method, and students participate voluntarily. Due to the lack of supporting teaching content, teachers, teaching system, and facilities, the activities are blind and random, and the cultivation of students' sports professional ability lacks comprehensiveness [8] and systematicness. For a long time, China's colleges and universities cannot meet the needs of the society for interdisciplinary professional sports talents, whether it is the teaching activities of general education courses [9], elective courses [9], professional courses [10], minor courses [11], or sports professional activities other than professional courses. At the same time, there are also some problems in the practice teaching: the goal of physical education practice teaching is not clear and not specific, and most of the teaching objectives are assimilative, not detailed, leading to students' learning enthusiasm being not high; sports professional practice teaching content lacks characteristics of the times and is out of touch with social and market demand. The management of physical education practice teaching is lacking independence and the management function is poor. The guarantee of practice teaching is not perfect and the level of guarantee is not high. The evaluation of practice teaching is lacking, and the evaluation effect needs to be improved.

Physical education in colleges and universities plays a positive role in improving students' personality, quality, and physique. In order to ensure physical health, develop basic 
sports skills, and understand sports knowledge and cultural knowledge, we should carry out physical education. In addition, physical education can also inspire future cadres and leaders, letting them know more scientific research methods, so that they can adhere to exercise, consolidate health, and hold various school sports activities. The arrangement of college physical education curriculum should be as follows: the arrangement of college physical education curriculum must be able to solve some educational tasks, such as providing students with the methods, contents, and basic theoretical knowledge of physical training with the skills, knowledge, and equipment of physical training and social and moral education, but the health of students is always the first. The purpose of this study is to understand and find out the current situation of physical education in colleges and universities and formulate corresponding countermeasures, comprehensively according to the conditions of each university and in line with the development of the whole country and then make some contributions to the development of college physical education. In order to achieve the above goals, this paper will solve the following aspects of work: first of all, the current situation of physical education in colleges and universities in recent years is summarized. Secondly, it studies how to improve the function of school physical education. Finally, the paper puts forward reasonable suggestions on how to improve the teaching methods of physical education and how to change extracurricular activities.

\section{Lifelong Education and Lifelong Physical Education}

2.1. Physical Education Classroom Teaching. With the rapid development of education, six or seven years have passed since the promulgation and implementation of the new curriculum standards, but in the implementation of the new curriculum standards, some physical education teachers have encountered some problems in their teaching practice [12]. If these problems cannot be solved in time, it will not only hinder the normal teaching activities of front-line physical education teachers, but also have a great impact on the implementation effect of physical education courses. Therefore, under the guidance of the new curriculum standards, the systematic and practical classroom teaching design is particularly important $[13,14]$. Physical education classroom teaching design is a bridge connecting sports teaching theory and practice, and through classroom teaching design, modern physical education theory can be quickly integrated into educational practice so that teachers can make physical education goals more forward-looking, choose physical education content more systematically, and develop optimal teaching plans through continuous improvement of teaching activities, so as to better serve the sports teaching practice [15].

2.2. Lifelong Sports. Scholars with different views have different views on the definition of lifelong sports. Professor Wang Shanze [16], who advocated lifelong sports in China, pointed out: "lifelong sports refers to one's lifelong physical exercise and physical education." The general textbook of college of physical education for all describes the significance of lifelong sports in this way: "from the starting point of life to the end of life, learning and participating in physical exercise activities make sports truly an indispensable part of people's life; the practical process of providing participation opportunities for activities in different periods and different areas of life with the goal of systematization and integration of sports." The so-called lifelong physical education is physical exercise and physical education throughout one's life. From the perspective of human life cycle [17], we can define "lifelong sports" as the sum of physical education and training received in one's life.

The modern mode of production has gradually changed from manual labor to mental labor. This requires workers to maintain their physical and mental health through certain means in their spare time to ensure that they adapt to the development of productivity. Physical exercise can only achieve the purpose of physical and mental health, so what kind of sports can accompany the whole life? In this context, lifelong sports came into being, conforming to the historical trend.

The Internet mobile information system applied in all aspects of high school teaching, including teaching tools, teaching content, classroom teaching interactive form, and teaching evaluation, etc., for learners, created a mobile and networked learning environment, for learners to master the mobile teaching platform information retrieval and management method, create personal learning network, which can be extended to extracurricular, embodied unicom learning theory teaching concept. The teaching quality evaluation $Q$ is as follows:

$$
Q=\lambda \sum_{i=1}^{n} f(x, y) d(x)+\phi \sum_{i=1}^{n} m(x, y) d(x)+\gamma \sum_{i=1}^{n} n(x, y) d(x) .
$$

The acceptance degree of middle school students in the teaching process $C$ is

$$
C=\frac{\phi \sum_{i=1}^{n} K(p, q) d(p)+\sum_{i=1}^{n} F(p, q) d(p)}{M+N} .
$$

Through the Internet mobile information system, students have learning speed $S$ of

$$
S=\frac{\kappa(p+q)}{T} .
$$

Among them, $\kappa$ is the corresponding parameters.

In addition to the influence of lifelong education thought, the formation of lifelong physical education thought [18] is also affected by the function of sports itself, the changes of people's life with the development of society, and the way of people's behavior. Lifelong sports were based on social development. As far as personal development is concerned, it starts from how individuals adapt to the needs of social development and from the issue of cultivating people's all-round development. From a certain stage of physical education teaching, it is not a complete physical education teaching process, but a whole process of physical education teaching. 
2.3. Relationship between Lifelong Sports and College Sports. School physical education [19] has a close relationship with lifelong physical education, which is included in the lifelong physical education system. Lifelong physical education is the continuation and development of college physical education.

(1) Physical education in colleges and universities is an important basis of lifelong physical education: Physical education in colleges and universities is an important process for people to carry out sports practice and physical education. It is also the basic stage of people's lifelong exercise. As an important part of lifelong physical education, college physical education is in the critical period of lifelong physical education; receiving regular physical education in school is the most systematic and standardized education for every student. College physical education is the most important and critical period for students to form lifelong sports habits. Colleges and universities are the base of cultivating talents, and physical education is the basis of cultivating talents. Qualified talents should not only have profound professional knowledge, but also have healthy physique. The function of sports can effectively improve and improve human health. Keeping healthy requires long-term and unremitting physical exercise. Physical education in colleges and universities should strengthen students' quality in time. The cultivation of subject consciousness can improve the ability of self-exercise, strengthen the concept of lifelong physical education, and master the correct knowledge and methods of physical exercise.

(2) Internet mobile information system refers to a software system that provides mobile learning information and learning support services through wireless communication technology or wireless network technology, mainly for mobile learning and personalized learning services. Mobile teaching platform can be divided into three categories: a short message learning platform, learning and sharing resources through text and language information, and a link-based learning platform, where learners need to access mobile teaching server through communication protocol, and a third interactive learning platform based on wireless network, where learners can use tablet and smartphone to conduct real-time interactive learning activities such as browsing and query.

(3) College sports and lifelong sports are complementary: college students are in the puberty of physical and mental maturity, which is also the key period for the formation of world outlook. Good physical education plays a positive role in improving one's own quality, forming the concept of lifelong physical education, and establishing the national health consciousness. Physical education in colleges and universities is the last link for students to accept physical education. It is the process of students' physical exercise in school and the link between school physical education and social sports. It can be said that physical education and physical exercise of young college students in school will directly affect the possibility of physical exercise in the future. It can be said that school physical education not only has an important impact on students' study and life in school, but also has a certain impact on students' family, life, and work after they enter the society. Therefore, the connection and transition between physical education and lifelong physical education is particularly important. College sports and social sports should be coordinated development.

In college physical education, enhancing students' physical health is the most important goal. But with the continuous improvement of China's economic conditions, people's pursuit of physical exercise is also constantly improving and deepening. More and more people take the initiative to ask for physical exercise, which shows that people began to have a new understanding of the nature and function of sports. For the young generation of college students, it is time to seize this opportunity, make full use of the opportunity of learning in colleges and universities, and make themselves master 1-2 physical exercise skills through college sports training, so as to lay the necessary sports foundation for the society and carry out comprehensive fitness physical exercise in the future.

\section{Reflections on the Problems of College Physical Education from the Perspective of Lifelong Physical Education}

3.1. Investigation on the Current Situation of College Students' Lifelong Sports Consciousness. The awareness of physical education based on the Internet mobile information system exists objectively in the human brain in response to motor phenomena, which is an understanding of physical exercise. This paper discusses the current situation of college students from the perspective of classroom sports cognition, sports emotion and interest, motor motivation, and movement attitude through consulting data and interview experts.

(1) Lifelong sports cognition: cognition [20] is a kind of unique subjective consciousness and reaction to objective things. For different objective things, human cognition is different. In fact, the understanding of lifelong sports is the sum of the understanding of lifelong sports, the importance of lifelong sports to the development of college students, and the mastery of the concept of lifelong sports.

(2) The emotion and interest of physical exercise: the embodiment of sports emotion is based on specific sports behavior. Physical exercise can stimulate students' mood, improve their interest, and show different emotional states in sports. Positive 
emotional state often makes students have a strong interest in physical exercise and sense of identity, so as to carry out long-term and stable physical exercise.

Interest is the best teacher; sports interest [21] refers to students having the subjective initiative of physical exercise and choosing to participate in it. Sports interest is one of the effective motivations for students to choose sports. It is the premise of cultivating students' lifelong sports consciousness and the basis of forming good sports habits.

\subsection{Influencing Factors of College Students' Lifelong Sports.} School factors: It is very important to stand on the last post to help students carry out lifelong sports. Some colleges and universities have unreasonable physical education arrangements, such as not choosing their favorite physical education courses, education courses being not enough to complete, lack of interest in sports courses, education courses not attractive to students, resulting in students having no interest in sports training, and so on.

Sports venues and sports facilities are not only the first choice for college students, but also the most important sports facilities for college students. School sports venues are mainly concentrated in outdoor venues, track and field venues, campus fitness track, and so on. However, because some sports venues are not open, economic conditions and school fitness facilities fees are not perfect and other reasons, most of the college students' after-school sports venues are still concentrated in the school sports venues; indoor venues fees forced some students who have the desire to fitness to stop. Therefore, strengthening the development and utilization of stadiums and stadiums and facilities maintenance is one of the starting points. Colleges and universities should realize the diversification of sports venues management [22]. They can make full use of the information technology of students' part-time jobs or venues. They can manage the stadium with high technology. This not only saves a lot of labor costs, but also saves a lot of time for students in the way of using sports venues, so that they can spend more energy on learning, and sports for them is also a "real" relaxation activity.

Factors of examination system: physical education course in colleges and universities naturally needs examination. Although there are different types of courses in specific colleges and universities, the same thing is that physical education scores of each university should be included in academic transcripts. It also means that if you "fail" in sports, you will not be able to get a degree and complete the course normally.

Personal safety factors [23]: Health knowledge should be mastered before physical exercise. In the process of physical exercise, sports injuries and accidents will inevitably occur, so we need a scientific method to deal with such emergencies. Therefore, it is very important to carry out lectures on sports health knowledge in colleges and universities. Students lack sports nursing knowledge; at the same time, the safety of physical exercise cannot be guaranteed, resulting in college students not fully participating in sports; when they are preparing to exercise, it affects the feeling and experience of sports, so they cannot achieve a good state of exercise. Therefore, colleges and universities should pay more attention to the management of sports and health and promote college students to carry out lifelong physical exercise.

3.3. Experimental Setup. A survey on cognition of lifelong sports: a total of 600 students, 300 men and women, were investigated in Ningxia University, Jilin University, and Lanzhou University, with investigation on the ways to cultivate the practical ability of physical education: classroom teaching, extracurricular practice, and social practice. There are three problems in the cultivation of sports practical ability: the government and society pay less attention to school policy, the relevant provisions of the school are vague, lacking specific accuracy, and students' understanding of practical ability is not enough. A total of 300 students were surveyed.

\section{Results and Discussion}

The results of the investigation are as follows.

As shown in Figure 1, only $20 \%$ of the students are familiar with lifelong sports. Only $35 \%$ of the students have heard of lifelong sports. $30 \%$ of the students say that they usually only know about lifelong sports but do not understand the real meaning. $15 \%$ of the students have not heard of lifelong sports. Data show that only $20 \%$ of the students have a good understanding of lifelong sports, and the degree of understanding is far from enough. This means that there is a lack of theoretical guidance and concept carding for students in college physical education teaching, the concept of lifelong sports is not conveyed in curriculum and content, and good lifelong sports consciousness is not formed, which hinders the formation and development of college students' lifelong sports consciousness.

As shown in Table 1, 43\% of the students think that they are "very happy" after the exercise, $47 \%$ of the students think they are "happier" after the exercise, only $4 \%$ of the students think they are "unhappy" after the exercise, and 6\% of the students feel "no feeling" after the exercise. Most of the students are in a good mood after physical exercise, which also reflects the positive impact of physical exercise on a person and greatly promotes the development of personal lifelong sports.

As shown in Figure 2, 38\% of the students are very satisfied with the physical education teaching arrangement; $42 \%$ of the students are satisfied with the physical education teaching arrangement; $17 \%$ are not satisfied with the physical education teaching arrangement; and 3\% of the students are very dissatisfied with the physical education teaching arrangement. It shows that there are unreasonable phenomena in the arrangement of physical education teaching in colleges and universities. For example, they did not choose their favorite physical education courses, there are not enough completed physical education courses, there is a lack of interest in sports courses, or physical education courses for students are not very attractive, resulting in 


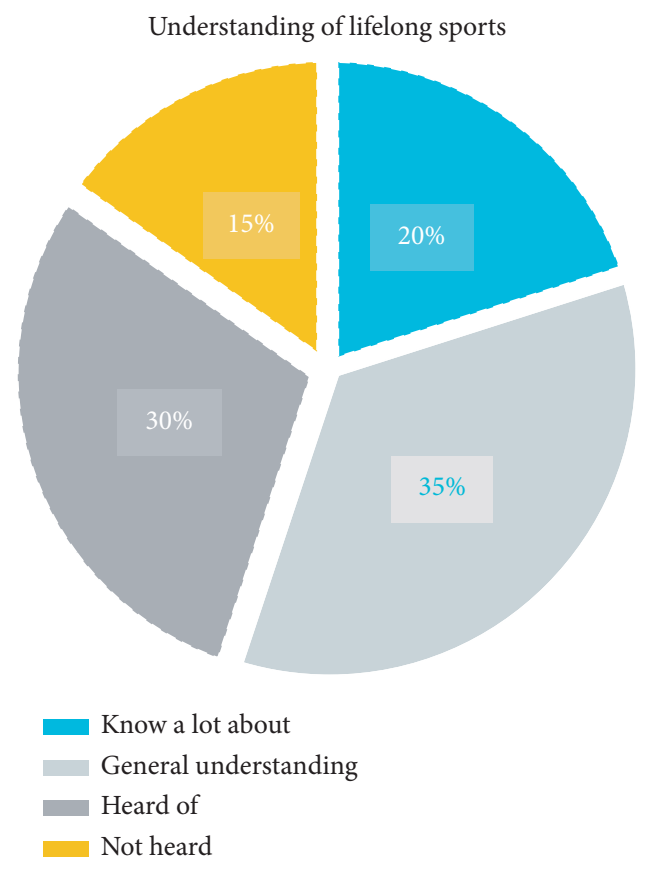

FIGURE 1: Understanding of lifelong sports.

TABLE 1: College students' emotion and interest in physical exercise.

\begin{tabular}{lcccc}
\hline & Very pleased & Happy & No feeling & Unhappy \\
\hline Number of people & 162 & 180 & 26 & 12 \\
Percentage & $43 \%$ & $47 \%$ & $6 \%$ & $4 \%$ \\
\hline
\end{tabular}
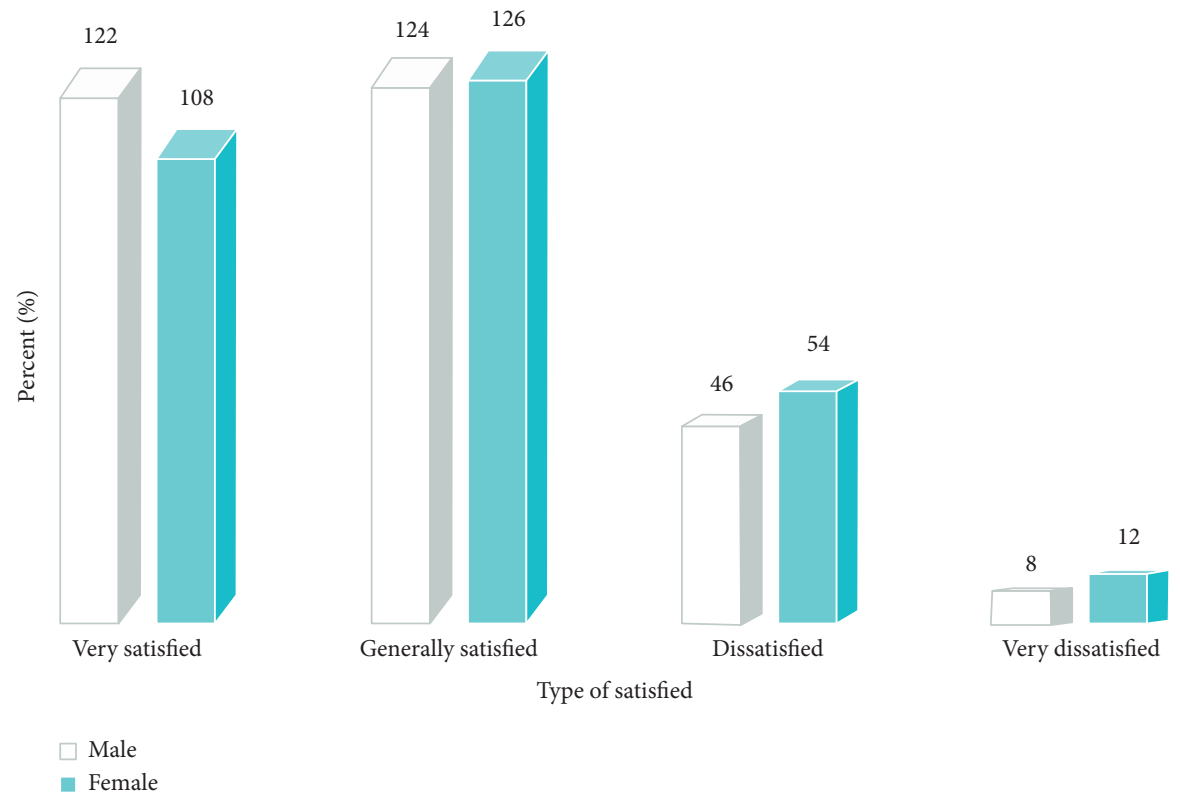

Figure 2: A survey of college PE curriculum satisfaction.

students lacking interests in physical exercise, indirectly reducing the awareness of lifelong sports.

As shown in Figure 3, there are three ways to cultivate students' practical ability: classroom teaching, extracurricular practice activities, and social practice activities. Among them, the ways to cultivate the practical ability of students majoring in physical education of Ningxia University are as follows: classroom teaching accounts for $14 \%$, extracurricular activities 


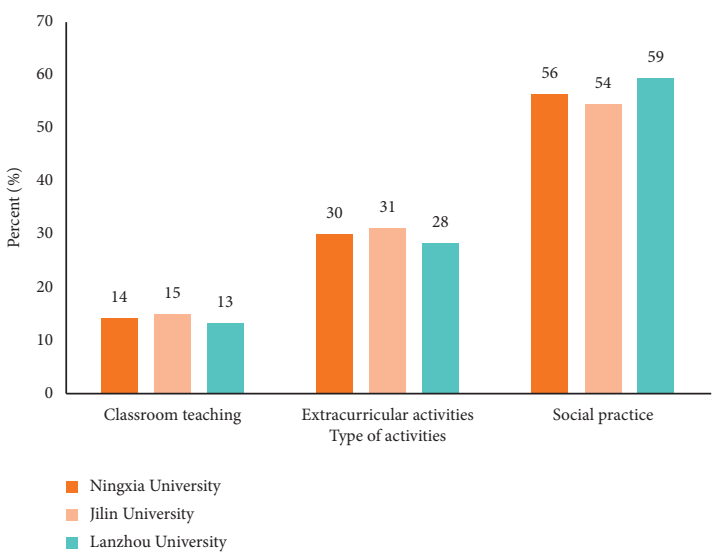

FIgURe 3: Ways to cultivate the practical ability of physical education.

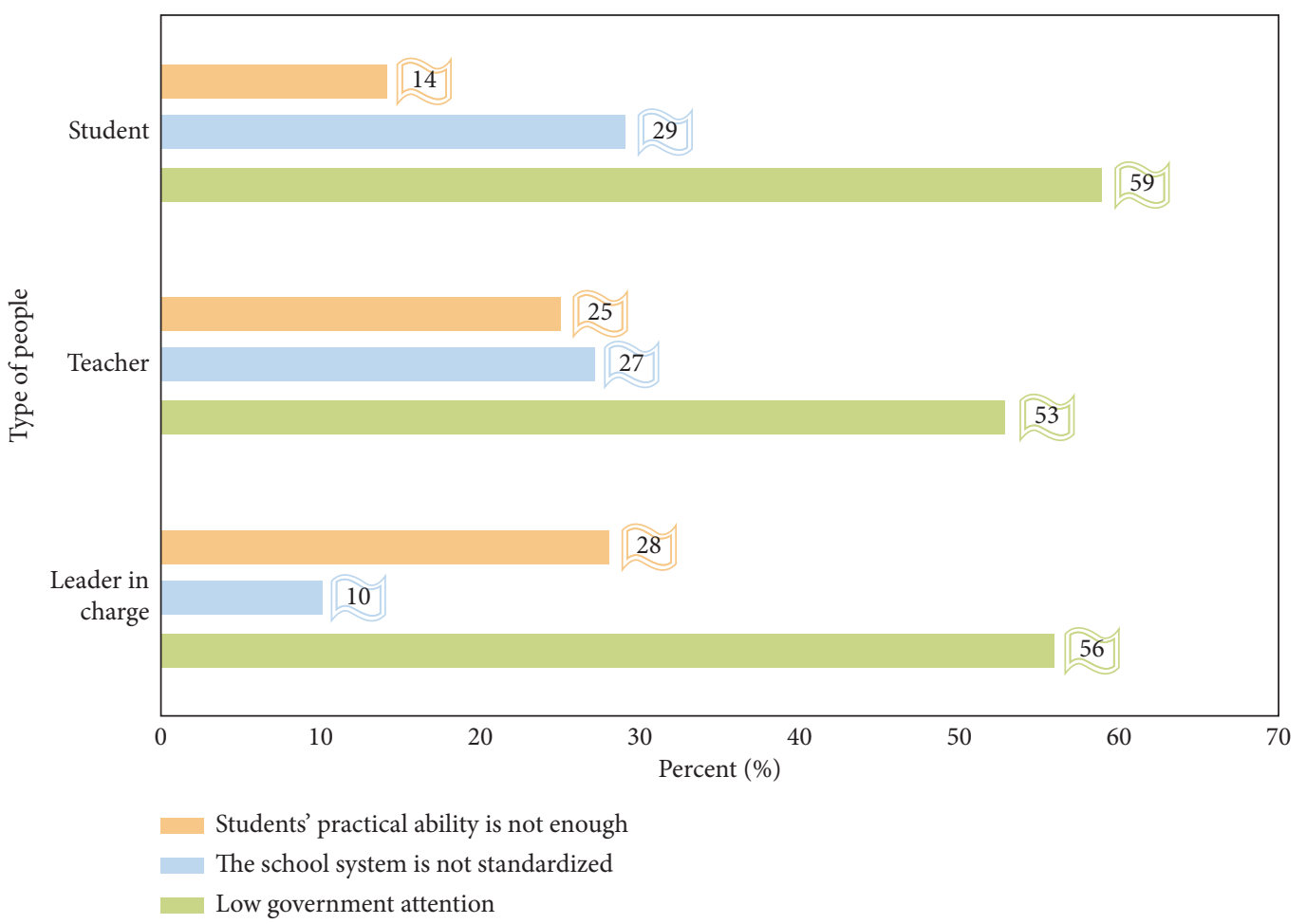

FIgure 4: Problems existing in the training of practical ability.

account for $31 \%$, and social practice accounts for $56 \%$; the cultivation methods of practical ability of students majoring in physical education of Physical Education College of Jilin University are classroom teaching 15\%, extracurricular activities $31 \%$, social practice $54 \%$; cultivating the practical ability of students majoring in physical education in Lanzhou Datong University, the way of strength is $13 \%$ of students having practical ability in classroom teaching, $28 \%$ in extracurricular activities, and $59 \%$ in social practice. It can be seen that the training methods of the three universities are mainly based on social practice, supplemented by extracurricular activities and a small amount of in-class teaching.

As shown in Figure 4, there are three problems in the cultivation of college students' sports practice ability. Firstly,
$53 \%$ of the teachers, $59 \%$ of the students, and $56 \%$ of the school leaders think that the government and the society pay less attention to the school policy; secondly, 29\% of the teachers, $27 \%$ of the students, and $10 \%$ of the school leaders think that the relevant provisions of the school are vague and lack specific accuracy; thirdly, 25\% of the teachers, $14 \%$ of the students, and $28 \%$ of the school leaders think that the students' understanding of the practical ability is not enough. The research shows that the government and society pay less attention to school policy, which is the main reason that affects students' sports practice ability.

Through the knowledge of physical education teachers on classroom teaching design, 35\% of PE teachers are more understanding of classroom teaching design; only $10 \%$ of 


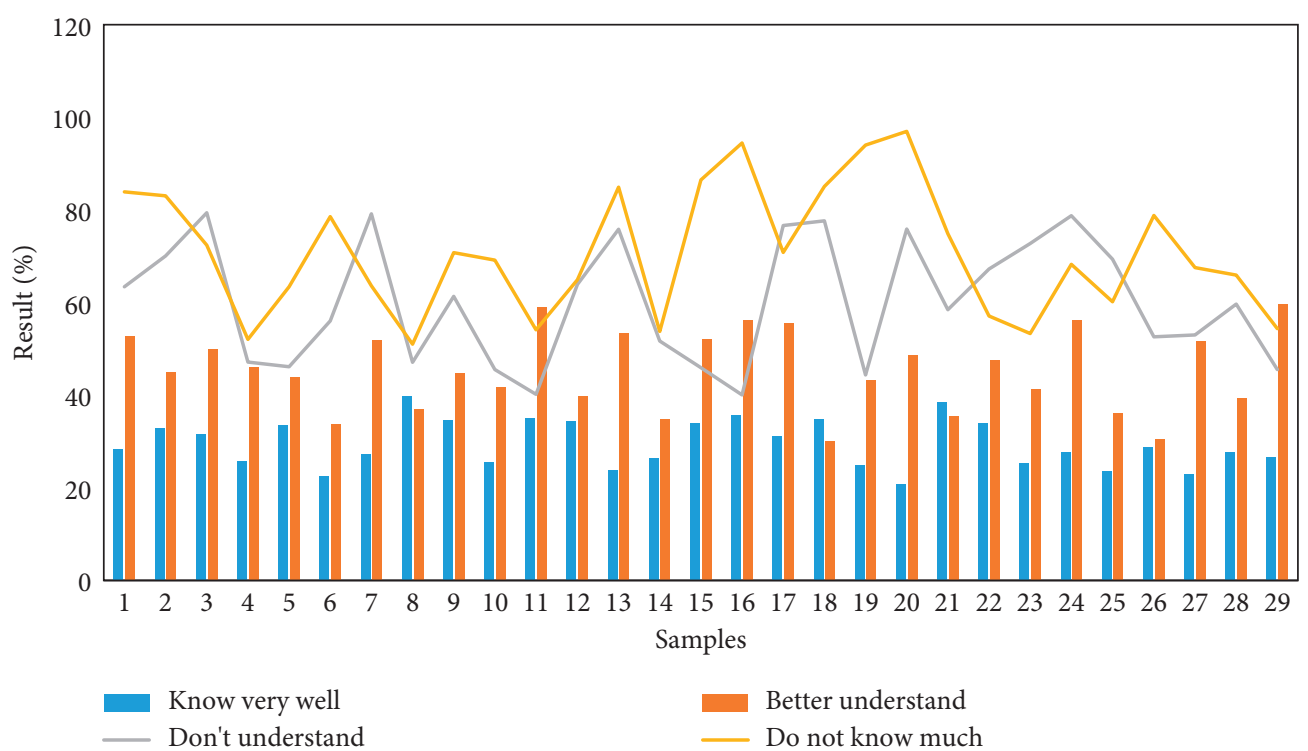

Figure 5: Physical education teachers' knowledge of the classroom teaching design.

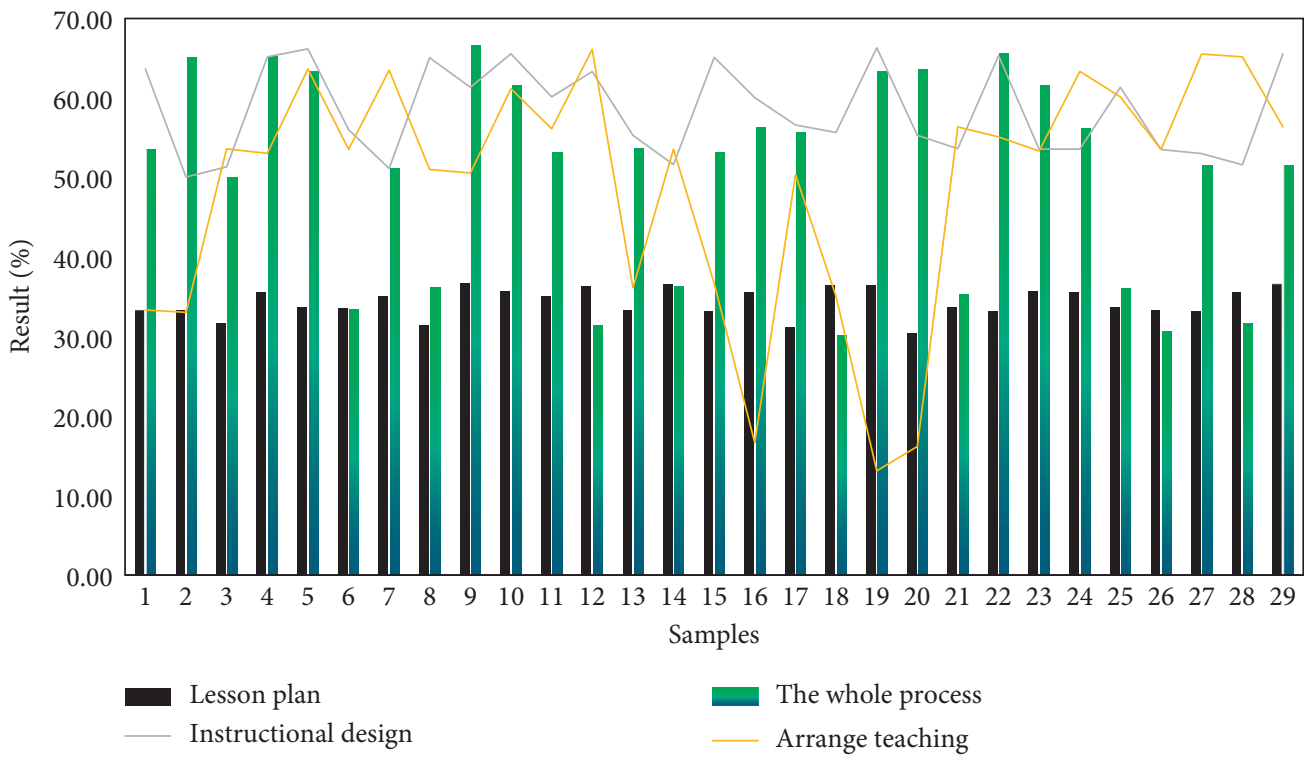

FIgURE 6: The physical education teacher's understanding of classroom teaching design.

these physical education teachers are very understanding of classroom teaching design; this shows that some university physical education teachers in our city have indeed contacted or learned about the relevant content of physical education classroom teaching design, but few teachers really learn sports classroom teaching design. Another $37.5 \%$ of physical education teachers know less about classroom teaching design; about $17.5 \%$ of physical education teachers are ignorant about classroom teaching design; it shows that the city university physical education teachers paying great attention to the design of classroom teaching are not enough, in order to avoid the differentiation of physical education teachers' understanding of classroom teaching design. Physical education teachers' knowledge of the classroom teaching design is shown in Figure 5.
$35 \%$ of teachers mistake the design of PE classroom teaching as teaching plans, which shows that PE teachers have some understanding of classroom teaching design, but there are misunderstandings about the relationship between the two; $40 \%$ have a correct understanding of the connotation of classroom teaching design, that is, the optimization process of class hours, units, and semester physical education. The other $25 \%$ of physical education teachers think that classroom teaching design is a teaching model or the whole process of a course. The physical education teacher's understanding of classroom teaching design is shown in Figure 6.

Teachers agree to $20 \%$ of using the Internet mobile information system to activate the atmosphere of the sports classroom. Teachers representing $20 \%$ of consent can 


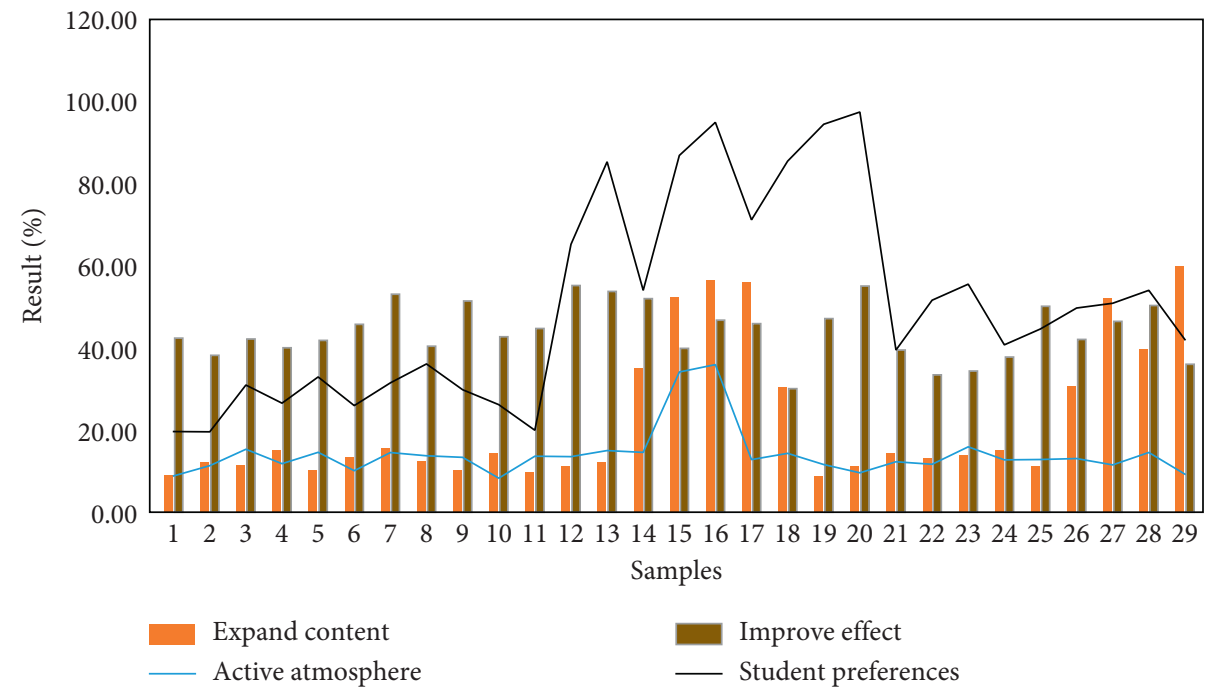

FIgURE 7: The evaluation of the teaching quality.

broaden the teaching capacity of PE classes. There are $30 \%$ of teachers who agree to improve the efficiency of physical education. There are $25 \%$ of teachers who can improve students' classroom concentration. $5 \%$ of teachers agreed to improve classroom results. The evaluation of the teaching quality is shown in Figure 7.

\section{Conclusion}

Classroom teaching design is composed of two parts: system and program. Objectively speaking, every physical education teacher will go through a variety of "design" processes in teaching, but many teachers' "design" is formed according to their own experience and will, so that this design often lacks a certain scientific and theoretical basis. The emergence of classroom teaching design has just changed this teaching phenomenon, classroom teaching design through the systematic consideration of all links of teaching, to establish a replicable and impart teaching technology. If physical education teachers can be familiar with mastering this classroom teaching design, studentcentered, health first guiding ideology, combined with the teaching theory of physical education, follow the characteristics of physical education, and conduct a systematic analysis of the teaching link, the teaching activities designed by physical education teachers will be scientific and reasonable. The shortcomings of this study are as follows: we cannot get the problems of lifelong physical education of college students in the whole country. We can only study the situation of individual schools, study random sample of students, and cannot estimate the situation of all students. By studying the problems in physical education in three colleges and universities, the conclusion is as follows: firstly, it is found that there is a lack of theoretical guidance and concept carding for students in college physical education, and college students do not form a good awareness of lifelong sports; secondly, the study shows that physical exercise has a positive impact on a person and promotes the development of physical education. It also finds out that the arrangement of physical education in colleges and universities is unreasonable. The training mode of colleges and universities is mainly based on social practice, with extracurricular activities attached and a small amount of in-class teaching. Finally, it finds out that the government and the society pay less attention to the school policy, which is one of the main reasons affecting students' sports practice ability, as well as the school's relationship. The relevant regulations are vague, lacking accuracy, and students lack practical ability. In view of the above research results, the author suggests that colleges and universities should reasonably arrange physical education teaching, set up popular physical education courses, and give more theoretical guidance, such as giving lectures and setting up sports competitions. It is also suggested that college students should take part in more physical exercises to strengthen their physique so as to better learn and realize themselves. The application of the Internet mobile information system in physical education will help promote the reform of teaching, but this is a brand-new teaching model, the development is not yet mature, and the schools have insufficient experience. Therefore, universities should establish information exchange platforms, develop cooperation mechanisms, and strengthen cooperation. Schools should upload their own mobile Internet sports teaching experience to the platform, enrich mobile Internet sports teaching resources, realize resource sharing, and promote the development of physical education. In the information age, it is inevitable to reform college physical education. The application of the mobile Internet has brought great advantages to physical education, strongly promoted the reform of physical education, and conformed to the development trend of the times. It is conducive to improving the level of physical education, cultivating comprehensive talents, and promoting the reform of higher education. 


\section{Data Availability}

No data were used to support this study.

\section{Conflicts of Interest}

The author declares that there are no conflicts of interest.

\section{References}

[1] W. D. Koenig, E. L. Walters, and P. G. Rodewald, "Testing alternative hypotheses for the cause of population declines: the case of the red-headed woodpecker," The Condor: Ornithological Applications, vol. 119, no. 1, pp. 143-154, 2017.

[2] M. Iovino, M. Castellini, V. Bagarello, and G. Giordano, "Using static and dynamic indicators to evaluate soil physical quality in a Sicilian area," Land Degradation \& Development, vol. 27, no. 2, pp. 200-210, 2016.

[3] Y. Jiang and Y. Wang, "Evaluation of teaching quality of public physical education in colleges based on the fuzzy evaluation theory," Journal of Computational and Theoretical Nanoscience, vol. 13, no. 12, pp. 9848-9851, 2016.

[4] L. Peternel, T. Petrič, and B. Jan, "Robotic assembly solution by human-in-the-loop teaching method based on real-time stiffness modulation," Autonomous Robots, vol. 42, no. 2, pp. 1-17, 2018.

[5] P. D. Loprinzi and E. Frith, "Motor skills and free-living physical activity showed no association among preschoolers in 2012 u.s. national youth fitness survey," Perceptual \& Motor Skills, vol. 124, no. 2, pp. 321-328, 2017.

[6] T. Zhou, X. Li, and H. Zhao, "Med-ppphis: blockchain-based personal healthcare information system for national physique monitoring and scientific exercise guiding," Journal of Medical Systems, vol. 43, no. 9, pp. 1-23, 2019.

[7] D. Landi, K. Fitzpatrick, and H. Mcglashan, "Models based practices in physical education: a sociocritical reflection," Journal of Teaching in Physical Education, vol. 35, no. 4, pp. 400-411, 2016.

[8] B. J. Solomon, D.-W. Kim, Y.-L. Wu et al., "Final overall survival analysis from a study comparing first-line crizotinib versus chemotherapy in alk-mutation-positive non-small-cell lung cancer," Journal of Clinical Oncology, vol. 36, no. 22, pp. 2251-2258, 2018.

[9] T. Ahmed and R. Chattopadhyay, "Return to general education and vocational education \& training in Indian context," International Journal of Educational Management, vol. 30, no. 3, pp. 370-385, 2016.

[10] J. M. Laguador, N. C. Camello, C. I. Dotong, N. H. Chavez, and E. L. D. Castro, "Divergence on students' interest in engineering program and academic performance in general and professional courses as input to k-12 engineering education," International Journal of Applied Engineering Research, vol. 11, no. 9, pp. 6824-6831, 2016.

[11] P. M. Rothwell, A. Buchan, and S. C. Johnston, "Recent advances in management of transient ischaemic attacks and minor ischaemic strokes," The Lancet Neurology, vol. 5, no. 4, pp. 323-331, 2016.

[12] A. Vidal and S. María, "Lifelong learning in bioethics and human rights: 10 years of the bioethics lifelong education programme in lac," International Journal of Ethics Education, vol. 1, no. 2, pp. 1-15, 2016.

[13] M. C. B. Ashley, G. Allen, C. S. Bonner, S. G. Bradley, X. Cui, and J. R. Everett, "The plato observatory: robotic astronomy from the antarctic plateau," Highlights of Astronomy, vol. 15, no. 15 , pp. 627-629, 2016.

[14] I. Scholtes, P. Mavrodiev, and F. Schweitzer, "From aristotle to ringelmann: a large-scale analysis of team productivity and coordination in open source software projects," Empirical Software Engineering, vol. 21, no. 2, pp. 642-683, 2016.

[15] S. Angona, "Islamismus-rechtsextremismus vergleichen?" Forschungsjournal Soziale Bewegungen, vol. 32, no. 1, pp. 93-97, 2019.

[16] C. H. Kim, Z. F. Zhang, L. S. Wang, and T. Sun, "Preparation of mno2-impregnated carbon-coated fe3o4 nanocomposites and their application for bovine serum albumin adsorption," Rare Metals, vol. 3, pp. 1-8, 2016.

[17] R. Dones, T. Heck, M. F. Emmenegger, and N. Jungbluth, "Life cycle inventories for the nuclear and natural gas energy systems, and examples of uncertainty analysis (14 pp)," International Journal of Life Cycle Assessment, vol. 10, no. 1, pp. 10-23, 2018.

[18] D. Parnell, S. Buxton, D. Hewitt, M. J. Reeves, E. Cope, and R. Bailey, "The pursuit of lifelong participation: the role of professional football clubs in the delivery of physical education and school sport in england," Soccer and Society, vol. 17, no. 2, pp. 225-241, 2016.

[19] J. L. Hollis, A. J. Williams, R. Sutherland et al., "A systematic review and meta-analysis of moderate-to-vigorous physical activity levels in elementary school physical education lessons," Preventive Medicine, vol. 86, no. 1, pp. 34-54, 2016.

[20] H. Y. Meltzer and T. Sumiyoshi, "Does stimulation of 5-ht(1a) receptors improve cognition in schizophrenia?" Behavioural Brain Research, vol. 195, no. 1, pp. 98-102, 2016.

[21] R. O. Deaner, S. M. Balish, and M. P. Lombardo, "Sex differences in sports interest and motivation: an evolutionary perspective," Evolutionary Behavioral Sciences, vol. 10, no. 2, pp. 73-97, 2016.

[22] A. Kirmer, K. Rydgren, and S. Tischew, "Smart management is key for successful diversification of field margins in highly productive farmland," Agriculture, Ecosystems \& Environment, vol. 251, no. 1, pp. 88-98, 2018.

[23] M. Allik and A. Kearns, "“There goes the fear": feelings of safety at home and in the neighborhood: the role of personal, social, and service factors," Journal of Community Psychology, vol. 45, no. 4, pp. 543-563, 2017. 